\title{
Fractionation of the Insoluble Brain Proteins with Acrylamide Electrophoresis ${ }^{1}$
}

\author{
RAMON IIM" AND FNOY TAI)AYYON

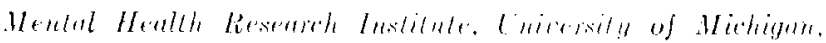

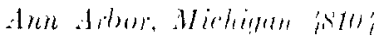

Rreeived July 25, 19609

Polyacrylamide gel electrophoresis as originated by Ornstein and Daris $(1,2)$ and Raymond (3) is an cxecllent method for the fractionation of soluble proteins. (In the other hand, the separation of membrane proteins poses considerable problems becallise of their low solubility in water and because of their large particle size. In this rexpect the following agents have been employed to solubilize or divaggregate complex proteins for acrylamide electrophoresis: urea (4-6). Triton X-100 (7, 8), sodium dodecylsulfate $(9,10)$, phenol $(11,12)$, and $\beta$-mercaptoethanol (7-10). However, carcful evaluations should be mate before applying such procedures to the insoluble proteins of the hrain because of the complexity of membrane organization and the high lipid content in this orgatil.

Sereral methods for fractionating insoluble brain proteins with acrylamide clcetrophorewis have been described. That of Cotman and Mahler $(13,14)$ uses phenol, acetic acid, water, and urea. That of Mehl (15) unes phenol, formic acid, and water. A method devined by Shooter (16) and his associates consists of solubilizing the proteins with Triton X-100, which is subsequently rephied by sodium dodecylinulfate before electrophoresis. In this report we evaluate the effects of the rarious solubilizing agents and the gel conditions, either singly or in rombinstion, on the acrylamide electrophoretic pattern of the insoluble brain proteins. The resulting technique is mainly a variation of the conditions preseribed by Neville (17) originally amployed for the platma membranes of the livel eells.

${ }^{1}$ Supported by at grant from the Nitional Institule of Mental Hoalth (MH-12506).

- Special Resetreh Follow of the National Institute of Mrntal Health. Present address: Division of Neurologiral surgery amd Department of Biorhemistry. University of Chicago, Chicago, Illinois 60637. 


\section{METHOJ)}

Protein pellets are dissolved in a "sample solvent" consisting of $50 \mathrm{~m} M$ $\mathrm{K}_{2} \mathrm{CO}_{2}, 8 \mathrm{M}$ urea, $10 \%(\mathrm{v} / \mathrm{v})$ mercaptoethanol, and $5 \%$ Triton X-100. Separation is effected by electrophoresis in polyacrylamide gels containing $5 M$ urea and $0.25 \%$ Triton $\mathrm{X}-100$ under a discontinuous acidic $\mathrm{pH}$. The complete ingredients of the stacking (upper) part and the separation (lower) part of the gel, together with the procedure to prepare them, are presented in Table 1. Fach gel segment is laycred with water and photopolymerized with a $30 \mathrm{~W}$ daylight fluorescent lamp for $1 \mathrm{hr}$. The upper electrode buffer ( $\mathrm{pH} 4.0$ ) contains $110 \mathrm{~m} M$ glycine, $16 \mathrm{~m} M$ acetic acid, and $5 \mathrm{M}$ urea. The lower buffer $(\mathrm{pH} 2.7)$ contains $4.6 \mathrm{M}$ acetic acid and $60 \mathrm{mM} \mathrm{KOH}$. After layering the sample and the addition of the tracking dye (methyl green), electrophoresis is conducted at room temperature with the protein bands migrating toward the cathode, using a current of $0.75 \mathrm{~mA}$ for stacking and $1.5 \mathrm{~mA}$ for separation for each cylindrical gel of $5 \mathrm{~mm}$ diameter. This procedure differs from Neville's (17) in the fol-

TABLL 1

\begin{tabular}{|c|c|c|c|c|}
\hline \multirow[b]{2}{*}{ Ingredient } & \multicolumn{2}{|c|}{$\begin{array}{c}\text { Simall-pore gel solution } \\
\text { (pH } 2.7 \text { ) }\end{array}$} & \multicolumn{2}{|c|}{$\begin{array}{l}\text { Large-pore gel solution } \\
\qquad \mathrm{pH} 5.91\end{array}$} \\
\hline & Ami. used & \multirow[t]{2}{*}{$\begin{array}{l}\text { Final roncon. } \\
\text { in gel }\end{array}$} & Amt. uned & \multirow[t]{2}{*}{$\begin{array}{l}\text { Final concen. } \\
\text { in gel }\end{array}$} \\
\hline & $\mathrm{A}$ & & (A: & \\
\hline Acrylamide & $7.00) \mathrm{gm}$ & $7.00 \%$ & $1.75 \mathrm{gm}$ & $1.75 \%$ \\
\hline BIs & $0.20 \mathrm{gm}$ & $0.20 \%$ & $0.20 \mathrm{gm}$ & $0.20 \%$ \\
\hline $10 M$ acetic acid & $5.80 \mathrm{ml}$ & $0.58 \%$ & $0.65 \mathrm{ml}$ & $65.00 \mathrm{~m} M$ \\
\hline $1 N \mathrm{KOH}$ & $0.75 \mathrm{ml}$ & $7.50 \mathrm{~m} M$ & $6.00 \mathrm{ml}$ & $60.00 \mathrm{~m} \cdot \mathrm{l} /$ \\
\hline Urea & $30.000 \mathrm{gm}$ & $5.00 \mathrm{~N}$ & $30.00 \mathrm{gm}$ & $5.00 M$ \\
\hline $25 \%$ Triton $\mathrm{X}-100$ & $1.00 \mathrm{~m} 1$ & $0.25 \%$ & $1.00 \mathrm{mI}$ & $0.25^{0}$ \\
\hline \multirow[t]{2}{*}{ Water } & $1090.00 \mathrm{ml}$ & - & $10 ! 90.00 \mathrm{ml}$ & +- \\
\hline & \multicolumn{2}{|c|}{ (B) } & \multicolumn{2}{|c|}{ (B) } \\
\hline Riboflavin & $2.00 \mathrm{mg}$ & $4 \times 10^{-+4}$ & $2.00 \mathrm{mg}$ & $4 \times 10^{-41}$ \\
\hline TEMED & $0.40 \mathrm{ml}$ & $8 \times 10^{-2} \%$ & - & - \\
\hline \multirow[t]{2}{*}{ Water } & to $50.00 \mathrm{ml}$ & - & $10.50 .00 \mathrm{ml}$ & - \\
\hline & \multicolumn{2}{|c|}{$\left(B^{\prime}\right)$} & \multicolumn{2}{|c|}{$\left\langle\mathrm{B}^{\prime}\right)$} \\
\hline $\begin{array}{l}\text { Ammonium persulfate } \\
\text { Solution } B\end{array}$ & $\begin{array}{r}25.00 \mathrm{mg} \\
1.0 \quad 5.00 \mathrm{ml}\end{array}$ & $5 \times 10^{-2} c$ & $\begin{array}{r}25.00 \mathrm{mg} \\
\text { (1) } 5.00 \mathrm{ml}\end{array}$ & $5 \times 10^{-2} \%$ \\
\hline
\end{tabular}

Solutions $A$ and $B$ are stocks. Solution $A$ is kept at, room temperature and does not deteriorate for at least 3 weeks. Solution $B$ is kept at $4^{\circ}$. Solution $B^{\prime}$ is made up before each use. The final gel solution comsists of 't parts $A$ and 1 part $B^{\prime}$. 
lowing respects. Instead of dissolving protoins first in $\mathrm{K}_{2} \mathrm{CO}_{3}$, we dissolve the pellet directly in a solution containing all the ingredients mentioned above, including the Triton. In this way not only is a greater portion of protein solubilized, but also more bands are observed in the gel. Cp to $10 \mathrm{mg}$ of membrane protein can be dissolved in $1 \mathrm{ml}$ of the solution, as is cvident by the clarity of the mixture and the lack of visible pellet after high-speed centrifugation. Wo incorporate $0.25 \%$ Triton into both parts of the gel (stacking and separation), whereas the urea conecntration in the gel is reduced. The low urea conecntration facilitates handling of the gel solutions, sine gel solutions containing 7-9 $/ \mathrm{H}$ urea frequently solidify even at room temperature. The presence of urea in the upper buffer is necessary for good results, although its concentration ('anl be lowered from 5 lo $3 \mathrm{M}$ in order to ensure a demsity difference between the upper buffer and the sample solution to be lavered. The presenee of Triton promotes gelation and also enhanees the separation of bands. Too much Triton can cause the protein to streak and the gel to slip out of the tube during electrophoresis.

\section{RHSTILTS ANI) DISCUSSION}

The protein pellet obtained after an whatustive extraction of a goldfish brain homogenate was used to demonstrate the effectiveness of the methor. When the pellet was solubilized and fractionated by the procedure described, as many as 30 protein hands were obscrved (Fig. 1, lower portion, gel F). The bankls were shapply delineated and widely distributed throughout the entire gel. No bands could be secn when the same sample was applied to the standarel alkaline gel system of Ditris (2) (Fig. 1, upper portion, gol F). Figure 1 burther shows that, at the various extraction steps, much protein that woulst have been excluded from the gel when using the Davis system was frartionated by our present procedure (gols $A$ to 6 . The freez-thawing and the sonication steps were exsential for obtaining good separation of fraction $\mathrm{F}$.

Several of the present conditions were alteped to determine their importanee for optimal separation of the protem hamb. Figure 2 show that the protein pattern having the greatest number of bands was obtained only in an acidie gel and only when all the ingredients were present (Fig. 2, J). When compared with related methods, such as that of Neville (17). that of Takayama ef al. (12), or the proesture of Cotman and Mahler $(13,14)$ (Fig. 2, I, K, I, respectively), the technique we deseribed still yields the best result for the fish brain. The last eiter method has been used for hrain proteins $(13,14)$ hut in our experience it carries some obvious drawbacks: 11 the protein bands are usually ill-defined and the background hata: (2) a prolonged soaking step is meressary to incorporate phenol into the gerl; 13 , a discontinume buffer 


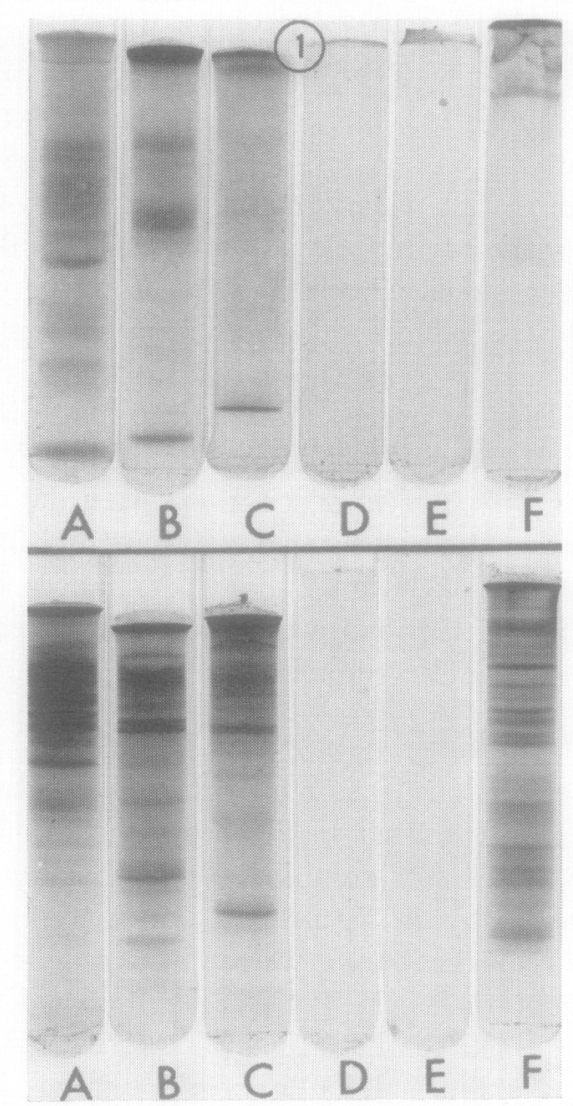

FIa, 1. Electrophoretic patterns of protein fractions obtained from a sequential rxtrartion procedure. A $10 \%$ goldfish brain homogenatr in isotonic saline was spun at $100,000 \mathrm{~g}$ for $30 \mathrm{~min}$ to obtain a supematant frartion $(A)$ and a pellet, which was subsequently extracted with water by similur entrifugations after freeze-thawing (B) and sonification (C). Thorough washing was carricd out after each extraction. The residue was again extracted twien with water ( $D$ and $F$ ) in order to cnsure the complete removal of water-soluble malerial, and the remaining pellet, taken as "insoluble brain protein," was then dissolved in the "sample solvent" as described in the toxt (F). The amounts of protein extracted in the various steps, expressed as the percentrge of the total in the homogenate. were $40,15,15,0.1,0.05$, and 30 , in that order: and the amounts applind to the polyarrylamide gels were $500,500,500$. 10,10 , and $500 \mu \mathrm{g}$. respectively. Protes in patterns in the upler half of the figure wer obfaimed according to the usual ronditions of Davis (2), whereas those in the lower half were achicund by the authors method of sample solubilization and electrophoresis. The same amount of protein was processed under both ronditions in gels having the same alphabetical designation. All gels were stained with $1 \%$ amido black in $7 \%$ aretic acid and destained hy soaking in sereral chimges of $7 \%$ aretir. arid. 


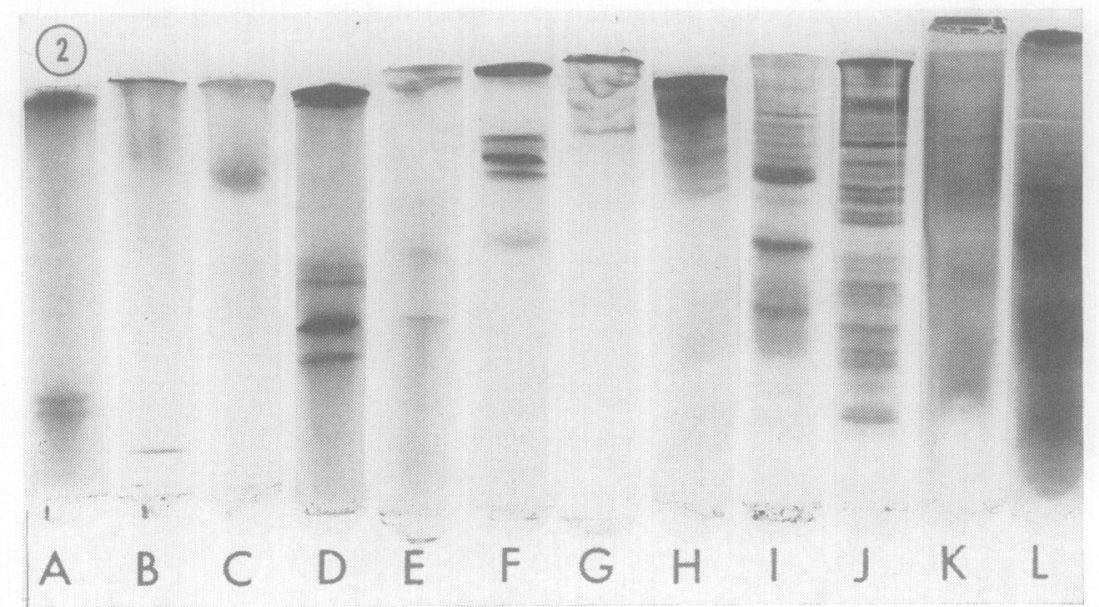

Fic. 2. Compration of varions methods for the frationation of insoluble brain proteins. The sime amount $(500 \mu$ ) of the insoluble hrain protein (see Fig. 1) was rxtrated by the different methods for protein solubilization and frationated by

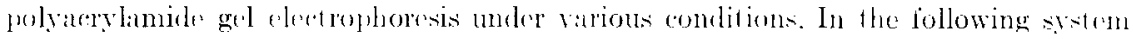
of designation, ledtere to the left of the bar indieate the type of colution werd for extraction, and those to the right denote the ingrentients adeled in the ger (in both the stacking and the soparation parts). Tnless oflerwise stated, in the extration solution, $\mathrm{T}=5 \%$, Triton $\mathrm{X}-100, \mathrm{I}^{\top}-8 . \mathrm{l}$ ura, $\mathrm{P}=50 \mathrm{~m} / \mathrm{l}$ potasium arbonate,

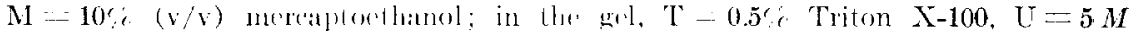
ura. The $\mathrm{pH}$ in geds $A$ to ( $i$ wats the disentinuous alkaline system of Davis (2). Thlat in $\mathrm{H}$ to $\mathrm{J}$ was the discontinuous acidie systrm of Nevillo (17). (A) $\mathrm{T} / \mathrm{T}$ : (B) L: U; (C) TU/TU; (D) TLP/TU; (E) TLM/TU: (F) TLMP TL; (G) TUMP/ no addition; (H) TUMP/T; (I) TUMP; and 9 / $/$ urea in stalking and separation farts, repectively; (J) TCMP/0.25, Triton X-100 plus $5 . M$ ureat (K) the extracetion and gel system of Takayama of al. (12): (L) the extraction and ged system of Cotman and Mahler (13, 11). The conditions for ged I were the original spexifietlions of Neville (17), those for gol J were authers moditiations, which were identiral with those for we $\mathrm{F}$ in the lower part of Figure 1 . (inel ( $\mathrm{i}$ is the same ats gel $\mathrm{F}$ in the upere part of Figure 1. All geds were stained and destaned as in Figure 1.

system cannot be employed. The use of solubilizing agents compatible with the polymerization step and with the formation of a discontinnous buffer system is a distinet advantage in our method as well as in Neville's (17).

In order to demonstrate the reproducibility of the band pattern, protein samples were simultancously clectrophoresed in a gel slab system. The gel was cast in the apparatus previously describud (18) using the reagents for the current method, with the following exeeptions. The ammonium persulfate in the stacking gel was raised to $0.10 \%$ to obtain better sample slots (altenatively the monomer concentration could be 


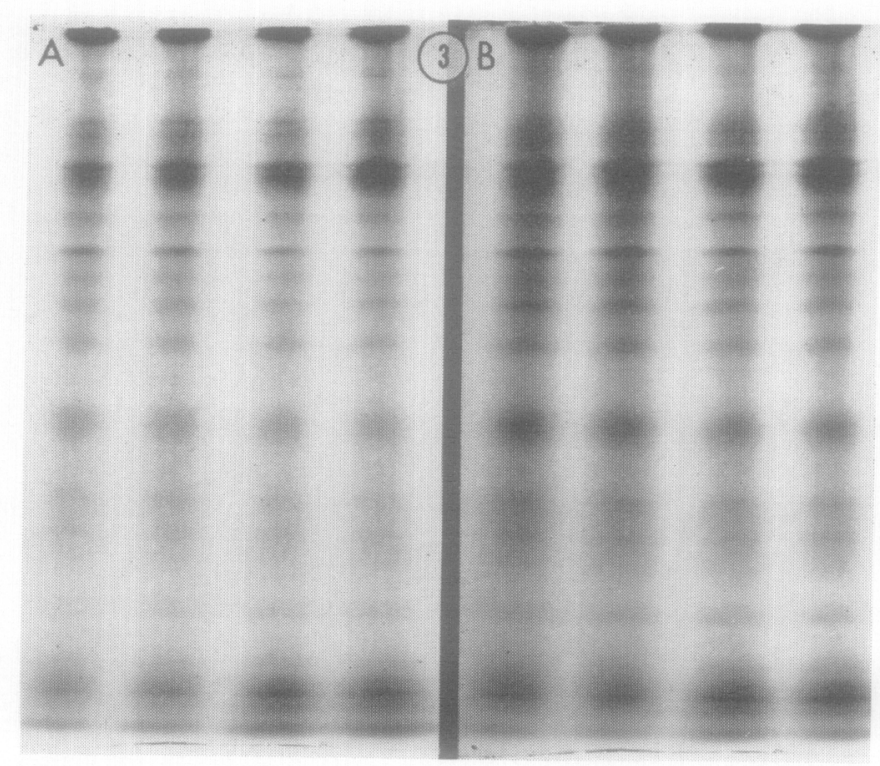

FIG. 3. Replicability of protein pattems in an :crylamide gel slat). (.) The samples used for the two leit slots were duplicates taken from a single pool (20 fish) of insoluble brain protein. Those for the two right slots were from another pool of 20 fish treated similarly. The gel systrm lised for J in Figure 2 wats mitst in the gel slab apparatus described earlior (18). The procedure used for obtaining insoluble protein in this experinent, was different from that deseribed in Figures 1 and 2. Instead of subjecting to stepwise centrifugations and washings, the entire homogenate: was freeze-thawed and sonicated. and then erntrifuged. The pollet obtained was thoroughly washed and solubilizerl. $500 \mu \mathrm{g}$ of this protein was applied to each slot. The gel was stained with amido black as with the cylindrical gels. (B) The same piece of gel stained with Coomassic brilliant blue aceording to the method of Fazekas de St. Groth (ser Chrambach) (19) for the intensification of bands.

increased). Since an edge effect was sometimes encountered with this gel system when used in the slab form, wedge-shape spacers were used to increase the width of the front as it traversed downward. Figure 3 shows that not only are protein patterns similar between duplicate samples taken from the same brain pool, but also they are comparable between different groups of animals when treated similarly. Such high degree of reproducibility makes the method suitable for rigorous comparison of individual protein bands.

\section{SUMMARY}

A method for fractionating the insoluble proteins of the brain with polyacrylamide electrophoresis is described. The procedure consists of dissolving the membrane proteins in a solution of urea, alkali, mercapto- 
'thanol, and Triton, and then conducting the separation in gels containing urea and Triton in discontinuous acidic buffers. As many as 30 sharp bands are discernable in the gel out of an insoluble brain fraction. The reproducibility of the band pattem is demonstrable in at gel slab systemen,

\section{ACKNOWLFI)(IMENT}

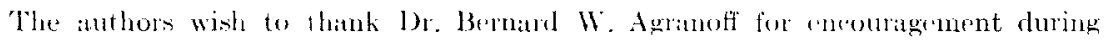
the actirs of this work.

\section{REHERLNCFS}

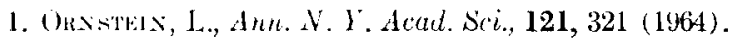

2. Davis, B. J.. Ann. N. Y. Acad. Sci., 121, 404 (1964).

3. Ramoxd, S., and Weictragb, L., Seience, 130, 711 (1959).

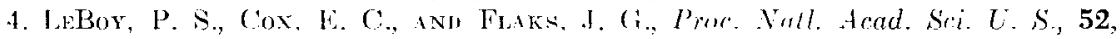
$1367(1964)$.

5. Jovis. Т.. Chrambarh, A., Axu Nabghros, M. A., Anel. Bienchem., 9, 351 (1964).

6. Molikr, W. and Chrambacil, A., J. Mol. Biol., 23, 377 (1967).

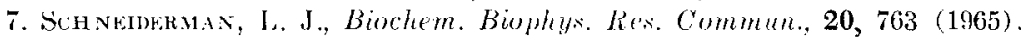

8. Schnemblimax, L., and Jintia, I. G., Biochemislty 7, 2281 (1968).

9. Summers, D. F., Maizha, J. V., and Daknill, J. E., Proc. Fall. Acad. Sci. U. S., 54, 505 (1965).

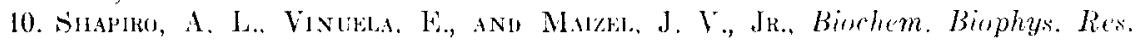
(romemum., 28, 815 (1967).

11. Work, T. S., J. Mol. Biol., 10, 544 (1964).

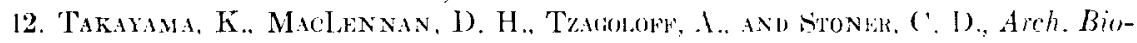
che'm. Biophys., 114, 223 (1964).

13. Cotmax, C. W., avo Manter, H. R., Arch, Binchem. Biophys., 120, 384 (1967).

14. Cotman. C. W. Manler, H. R., axv Hugu, T. E., Arch. Biochem. Biophys., 126, 821 (1968).

15. Mirl. F., in "Macromolesules and the Funetion of the Neuron" (Z. Lodin and S. P. R. Rose, cds.), p. 22. Exerpta Mcdiea Foundation, Amaterdam, 1968.

16. Sноотен, E., personal rommunication (1968).

17. Neville, D. M., Biochim. Biophy:. Acta, 133, 168 (1967).

18. Iim, R., Huinri, J. J., And Davis, (i. A., Anal. Biochem., 29, 48 (1969).

19. Chrimbach, A., Reisfietd, R. A.. Wrckofr, M., and Zacraki, J., Anal. Biochem.. 20, 150 (1967). 